\title{
Resonance assignments for latherin, a natural surfactant protein from horse sweat
}

\author{
Steven J. Vance $\cdot$ Rhona E. McDonald • \\ Alan Cooper • Malcolm W. Kennedy • \\ Brian O. Smith
}

Received: 8 March 2013/Accepted: 21 May 2013/Published online: 26 May 2013

(C) The Author(s) 2013. This article is published with open access at Springerlink.com

\begin{abstract}
Latherin is an intrinsically surfactant protein of $\sim 23 \mathrm{kDa}$ found in the sweat and saliva of horses. Its function is probably to enhance the translocation of sweat water from the skin to the surface of the pelt for evaporative cooling. Its role in saliva may be to enhance the wetting, softening and maceration of the dry, fibrous food for which equines are adapted. Latherin is unusual in its relatively high content of aliphatic amino acids $(\sim 25 \%$ leucines) that might contribute to its surfactant properties. Latherin is related to the palate, lung, and nasal epithelium carcinoma-associated proteins (PLUNCs) of mammals, at least one of which is now known to exhibit similar
\end{abstract}

S. J. Vance $\cdot$ A. Cooper

School of Chemistry, College of Science and Engineering,

University of Glasgow, Glasgow G12 8QQ, UK

Present Address:

S. J. Vance

Department of Biochemistry, School of Biological Sciences,

University of Cambridge, Cambridge CB2 1GA, UK

R. E. McDonald · M. W. Kennedy $(\square) \cdot$ B. O. Smith $(\square)$ Institute of Molecular, Cell and Systems Biology, College of Medical, Veterinary and Life Sciences, University of Glasgow, Glasgow G12 8QQ, UK

e-mail: malcolm.kennedy@glasgow.ac.uk

B. O. Smith

e-mail: Brian.Smith@glasgow.ac.uk

R. E. McDonald · M. W. Kennedy

Institute of Biodiversity, Animal Health and Comparative

Medicine, College of Medical, Veterinary and Life Sciences,

University of Glasgow, Glasgow G12 8QQ, UK

Present Address:

R. E. McDonald

Life Sciences Lead, Strategic Trade, UK Trade and Investment,

1 Victoria Street, London SW1H 0ET, UK surfactant activity to latherin. No structures of any PLUNC protein are currently available. ${ }^{15} \mathrm{~N},{ }^{13} \mathrm{C}$-labelled recombinant latherin was produced in Escherichia coli, and essentially all of the resonances were assigned despite the signal overlap due to the preponderance of leucines. The most notable exceptions include a number of residues located in an apparently dynamic loop region between residues 145 and 154 . The assignments have been deposited with BMRB accession number 19067.

Keywords Latherin - Surfactant protein - Horse - Sweat . Saliva $\cdot$ Allergen $\cdot$ NMR

\section{Biological context}

Several types of unrelated proteins appear to exhibit intrinsic surfactant activity as their primary function, which, for the moment, appears to be the case for latherin. Latherin is one of the most abundant proteins in the sweat of horses, it is also found in horse saliva, and is a known allergen to some humans (McDonald et al. 2009). Latherin's function is believed to be to wet the hydrophobic hairs in order to enhance the rate of translocation of sweat water to the surface of the pelt for evaporative cooling (McDonald et al. 2009). The hydrophobins, a family of surface active proteins produced by filamentous fungi, and RSN-2, a surfactant protein present in the foam nests of certain species of frogs, have been investigated at the protein structure level (Linder 2009; Cooper et al. 2005; Fleming et al. 2009). Latherin exhibits no amino acid sequence similarities to either of these proteins, but is instead a member of the palate, lung, and nasal epithelium carcinoma-associated family of proteins (PLUNCs) found in mammals (McDonald et al. 2009). Latherin and PLUNCs are, in turn, related to the larger, two-domain bactericidal/permeability-increasing 
protein (BPI), cholesteryl ester-transfer protein (CETP) and lipopolysaccharide-binding protein (LBP). Although the functions of individual PLUNCs have not been confirmed, they are postulated to have some role within the innate immune response (Bingle and Craven 2002). The structures of BPI and CETP are available, but no structure for any member of the PLUNC family has thus far been reported.

Latherin's amino acid sequence is unusually rich in aliphatic residues, in particular leucine, which contributes almost $25 \%$ of the residues present, compared to the SwissProt average for all proteins within that database of $9.67 \%$ (McDonald et al. 2009). This abundance of leucines is also a feature of one of the PLUNCs from humans that, like latherin, exhibits strong surfactant activity (Gakhar et al. 2010). Latherin, therefore, not only presents an opportunity to investigate the relationship between structure and function of a unique surfactant protein of mammals, but potentially also to understand the structure and function of the PLUNCs as a whole, for which there is currently little or no structural and direct functional information.

\section{Methods and experiments}

A synthetic latherin (sLath) gene based upon the previously described, cDNA encoding latherin (GenBank AF491288;
UniProt/Swiss-Prot P82615), excluding the presumptive secretory leader/signal peptide, optimised for expression in Escherichia coli, was purchased from GeneArt. The sLath gene was then directionally inserted into the NcoI, BamHI sites of the pET32a expression vector (Novagen) allowing for the production of recombinant latherin extended by two extra amino acids, AM (single letter amino acid code) at the N-terminus of the wild-type sequence. The "sLath/ pET32' plasmid was transformed into Tuner (DE3) cells (Novagen). Expression was carried out in Luria-Bertani broth for non-labeled samples or M9 minimal media (Sambrook et al. 1989) containing the relevant isotope(s) for the production of single $\left({ }^{15} \mathrm{~N}\right.$ only) or double $\left({ }^{15} \mathrm{~N},{ }^{13} \mathrm{C}\right)$ labeled samples. The protein was purified to near homogeneity as estimated from SDS-PAGE electrophoresis, as described previously (McDonald et al. 2009).

For the purpose of NMR, protein was concentrated to approximately $600 \mu \mathrm{M}$ in $50 \mathrm{mM} \mathrm{NaCl}, 20 \mathrm{mM}$ sodium phosphate, $1 \mathrm{mM}$ sodium azide, $\mathrm{pH}$ 7.5. $\mathrm{D}_{2} \mathrm{O}$ was added to a final concentration of $5 \%(\mathrm{v} / \mathrm{v})$. All experiments were performed at $310^{\circ} \mathrm{K}$ using a Bruker AVANCE $600 \mathrm{MHz}$ spectrometer equipped with $5 \mathrm{~mm}$ triple-resonance probes and pulsed-field gradients. The WATERGATE tailored selective excitation sequence was typically used for water suppression (Piotto et al. 1992). Proton chemical shifts were referenced
Fig. 1 The ${ }^{15} \mathrm{~N}$ HSQC spectrum of latherin at $310 \mathrm{~K}$. The residue specific assignments are indicated and the crosspeaks assigned to sidechain $\mathrm{NH} 2$ groups are linked by horizontal dashed lines

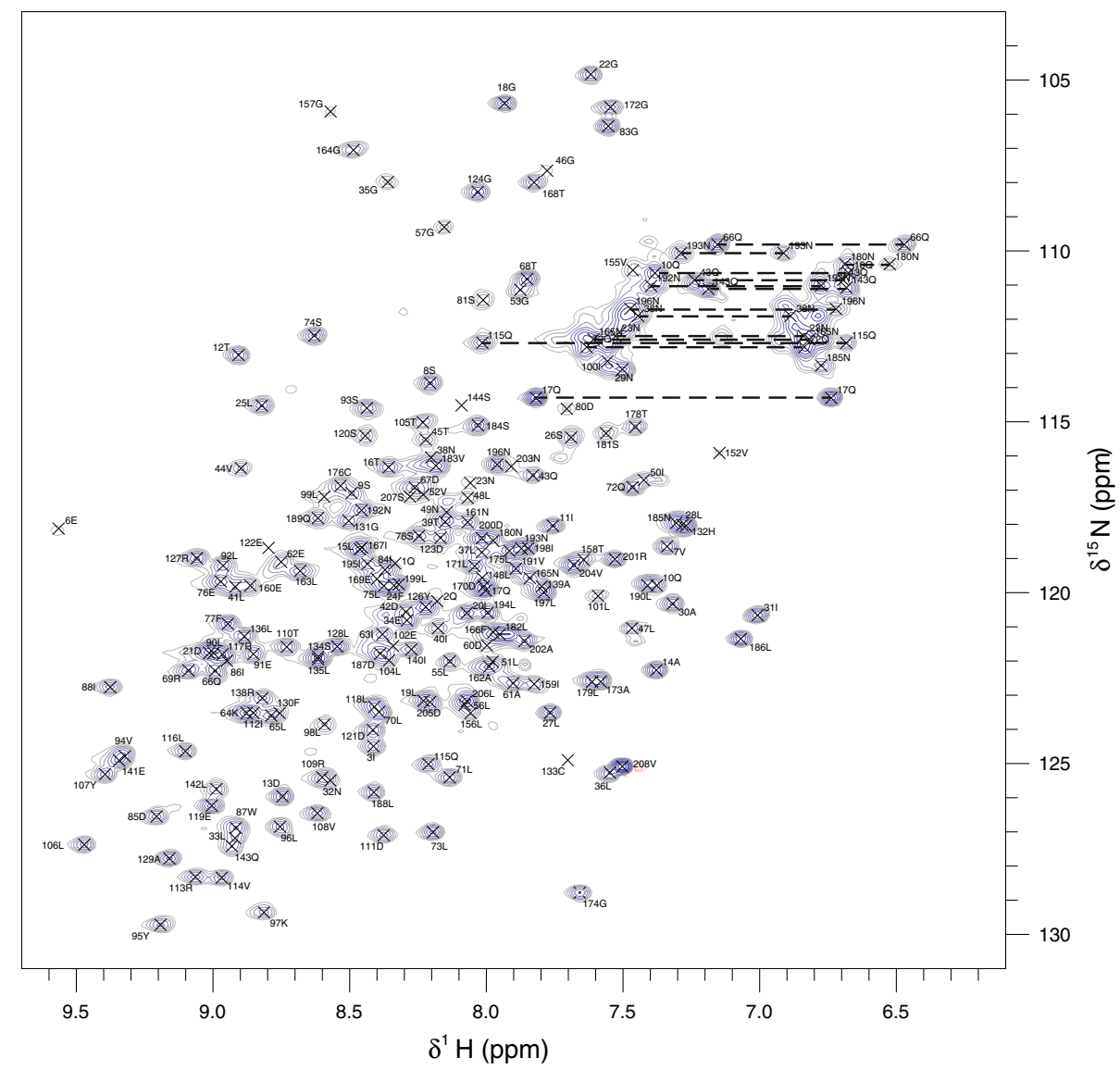


Fig. 2 The methyl region of the

${ }^{13} \mathrm{C},{ }^{1} \mathrm{H}$ correlation spectra of latherin illustrating the increased resolution of the leucine methyl crosspeaks possible with a the me-HCCHTOCSY experiment as compared to $\mathbf{b}$ the conventional ${ }^{13} \mathrm{C}-\mathrm{HSQC}$

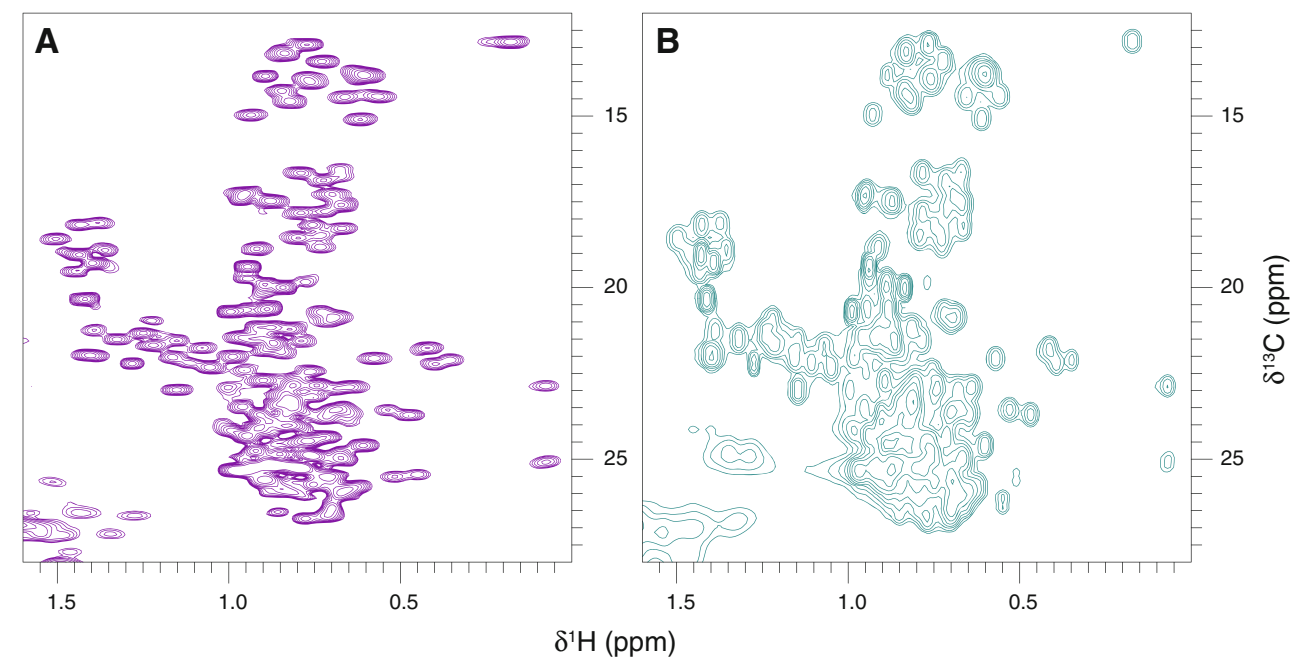

relative to the $\mathrm{H}_{2} \mathrm{O}$ offset frequency and heteronuclear chemical shifts calculated from the proton reference according to the method of Wishart et al. (1995). NMR spectra were processed using AZARA (Wayne Boucher, Department of Biochemistry, University of Cambridge, http://www.bio.cam. ac.uk/azara) and assigned using CCPNmr analysis (Vranken et al. 2005). Maximum entropy reconstruction (Laue et al. 1986) was used to enhance resolution of the indirect dimensions of three-dimensional experiments.

Sequence-specific resonance assignment of the latherin backbone was accomplished with the aid of $2 \mathrm{D}{ }^{15} \mathrm{~N}-\mathrm{HSQC}$ (see Fig. 1), 3D HNCACB, 3D CBCA(CO)NH (Muhandiram and Kay 1994), 3D HNCO (Kay et al. 1994), 3D HNCACO, 3D HBHA(CBCA)NH (Wang et al. 1994) and HBHA(CBCACO)NH spectra. The majority of aliphatic sidechain carbon and proton resonances were located by navigating from the backbone data using $2 \mathrm{D}{ }^{13} \mathrm{C}-\mathrm{HSQC}$, 3D (H)C(CO)NH-TOCSY, 3D and 3D H(C)(CO)NHTOCSY spectra (Grzesiek and Bax 1992). The high number of overlapping leucine sidechain resonances were assigned using 3D methyl-selective experiments (Uhrin et al. 2000) modified for the removal of $\mathrm{CH}_{2}$ resonances from the methyl proton-carbon planes (see Fig. 2). Remaining aliphatic resonances were identified using 3D ${ }^{13} \mathrm{C}$-edited $\left[{ }^{1} \mathrm{H},{ }^{1} \mathrm{H}\right]$-NOESY spectra. A proportion of aromatic sidechain ${ }^{13} \mathrm{C} /{ }^{1} \mathrm{H}$ signals (histidine $\mathrm{H} \delta 1$, tryptophan $\mathrm{H} \delta 1$, tyrosine $\mathrm{H} \delta, \varepsilon$ and phenylalanine $\mathrm{H} \delta, \varepsilon$ ) were assigned using 2D HBCBCGCDHD and 2D HBCBCGCDCEHE spectra (Yamazaki et al. 1993) and the remainder were identified from the ${ }^{13} \mathrm{C}$-edited $\left[{ }^{1} \mathrm{H},{ }^{1} \mathrm{H}\right]$-NOESY spectrum.

\section{Extent of assignments and data deposition}

All latherin polypeptide backbone resonances were assigned, with the exception of the $\mathrm{N}$-terminal residues
$\mathrm{A}(-2), \mathrm{M}(-1), \mathrm{A}(0)$; two isolated residues $\mathrm{S} 59, \mathrm{~K} 82$; and a number of residues located on a dynamic loop region (G145, N146, S149, L150, N153, A154). A total of $93.51 \%$ of backbone residues were identified, while assignment of non-labile amino acid sidechain protons is $94.23 \%$ complete. The majority of the missing assignments are those of the residues within the 145-154 residue dynamic loop region. Despite their high relative abundance within the protein, the experiments nevertheless allowed full assignment of all leucine residues. A few resonances displayed chemical shifts outwith the known distribution of shifts. Sidechain protons in residues $(85 \mathrm{D}$, $113 \mathrm{R}$ and $180 \mathrm{~N}$ ) all displayed the effects of ring current shift due to their close proximity to aromatic residues. 135L $\mathrm{C}_{\gamma}$ has an atypical chemical shift of $31.09 \mathrm{ppm}$. This residue is buried within the hydrophobic core of the protein surrounded by other aliphatic residues, and analysis of its stereochemical properties in the calculated structure indicated $\varphi, \Psi, \chi_{1}$ and $\chi_{2}$ bond angles in favourable regions. The atypical chemical shift in $135 \mathrm{~L}$ therefore remains to be explained.

The ${ }^{1} \mathrm{H},{ }^{13} \mathrm{C}$ and ${ }^{15} \mathrm{~N}$ chemical shift assignments have been deposited with the BioMagResBank database (http:// www.bmrb.wisc.edu), accession number 19067.

Acknowledgments This work was supported by a Wellcome Trust Showcase award (Grant Ref. 070994) to MWK and AC, and a studentship grant from the Biotechnology and Biological Sciences Research Council (UK) to AC and MWK. The NMR facility was funded by the Wellcome Trust through a grant to BOS and AC. The funders had no role in study design, data collection and analysis, decision to publish, or preparation of the manuscript.

Open Access This article is distributed under the terms of the Creative Commons Attribution License which permits any use, distribution, and reproduction in any medium, provided the original author(s) and the source are credited. 


\section{References}

Bingle CD, Craven CJ (2002) PLUNC: a novel family of candidate host defence proteins expressed in the upper airways and nasopharynx. Hum Mol Genet 11(8):937-943

Cooper A, Kennedy MW, Fleming RI, Wilson EH, Videler H, Wokosin DL, Su TJ, Green RJ, Lu JR (2005) Adsorption of frog foam nest proteins at the air-water interface. Biophys $\mathbf{J} 88(3)$ : 2114-2125

Fleming RI, Mackenzie CD, Cooper A, Kennedy MW (2009) Foam nest components of the túngara frog: a cocktail of proteins conferring physical and biological resilience. Proc R Soc B 276(1663):1787-1795. doi:10.1098/rspb.2008.1939

Gakhar L, Bartlett JA, Penterman J, Mizrachi D, Singh PK, Mallampalli RK, Ramaswamy S, McCray PB Jr (2010) PLUNC is a novel airway surfactant protein with anti-biofilm activity. PLoS ONE 5(2):e9098. doi:10.1371/journal.pone.0009098

Grzesiek S, Bax A (1992) Improved 3D triple-resonance NMR techniques applied to a $31 \mathrm{kDa}$ protein. Journal of Magnetic Resonance (1969) 96(2):432-440

Kay LE, Xu GY, Yamazaki T (1994) Enhanced-sensitivity tripleresonance spectroscopy with minimal $\mathrm{H} 2 \mathrm{O}$ saturation. J Magn Reson, Ser A 109(1):129-133

Laue ED, Mayger MR, Skilling J, Staunton J (1986) Reconstruction of phase-sensitive two-dimensional NMR spectra by maximum entropy. J Magn Reson 68(1):14-29

Linder MB (2009) Hydrophobins: proteins that self assemble at interfaces. Curr Opin Colloid Interface Sci 14(5):356-363. doi: 10.1016/j.cocis.2009.04.001

McDonald RE, Fleming RI, Beeley JG, Bovell DL, Lu JR, Zhao X, Cooper A, Kennedy MW (2009) Latherin: a surfactant protein of horse sweat and saliva. PLoS ONE 4(5):e5726
Muhandiram DR, Kay LE (1994) Gradient-enhanced triple-resonance three-dimensional NMR experiments with improved sensitivity. J Magn Reson, Ser B 103(3):203-216

Piotto M, Saudek V, Sklenář V (1992) Gradient-tailored excitation for single-quantum NMR spectroscopy of aqueous solutions. J Biomol NMR 2(6):661-665. doi:10.1007/bf02192855

Sambrook J, Fritsch EF, Maniatis T (1989) Molecular cloning: a laboratory manual, vol 1. Cold Spring Harbor Laboratory, Laurel Hollow, NY

Uhrin D, Uhrinova S, Leadbeater C, Nairn J, Price NC, Barlow PN (2000) 3D HCCH3-TOCSY for resonance assignment of methylcontaining side chains in C-13-labeled proteins. J Magn Reson 142(2):288-293

Vranken WF, Boucher W, Stevens TJ, Fogh RH, Pajon A, Llinas M, Ulrich EL, Markley JL, Ionides J, Laue ED (2005) The CCPN data model for NMR spectroscopy: development of a software pipeline. Proteins 59:687-696

Wang AC, Lodi PJ, Qin J, Vuister GW, Gronenborn AM, Clore GM (1994) An efficient triple-resonance experiment for protondirected sequential backbone assignment of medium-sized proteins. J Magn Reson, Ser B 105(2):196-198

Wishart DS, Bigam CG, Yao J, Abildgaard F, Dyson HJ, Oldfield E, Markley JL, Sykes BD (1995) ${ }^{1} \mathrm{H},{ }^{13} \mathrm{C}$ and ${ }^{15} \mathrm{~N}$ chemical shift referencing in biomolecular NMR. J Biomol NMR 6(2): 135-140. doi:10.1007/bf00211777

Yamazaki T, Forman-Kay JD, Kay LE (1993) Two-dimensional NMR experiments for correlating carbon-13.beta. and proton.delta./.epsilon. chemical shifts of aromatic residues in 13Clabeled proteins via scalar couplings. J Am Chem Soc 115(23):11054-11055. doi:10.1021/ja00076a099 